\title{
VIIT-TIFR Collaboration for Final Year Engineering Undergraduate Projects: A Novel Paradigm
}

\author{
C S Garde \\ Vishwakarma Institute of Information Technology, S. No. 2/3/4, Kondhwa \\ (Bk), Pune - 411048, India
}

\begin{abstract}
Engineering undergraduate students carry out a project in their final year. Many of these projects end up being mere study experiments which are never implemented in an industry or a research institute. We have identified the root causes for this failure and have developed a novel paradigm which has helped in carrying out projects in collaboration with Tata Institute of Fundamental Research (TIFR) which are subsequently deployed in an ongoing scientific experiment. Thus, TIFR gets state-of-the-art technology, faculty of our college, Vishwakarma Institute of Information Technology (VIIT), gets exposure to research laboratory and students learn, first hand, the nuances of technology development. It is thus a win-win situation for all the stake holders.
\end{abstract}

\section{S Garde}

Vishwakarma Institute of Information Technology,

S. No. 2/3/4, Kondhwa (Bk), Pune - 411048, India

\section{Introduction}

Development of cutting edge technology and its successful deployment is the key to growth of any country. India, in particular, can aspire to become a super power if and only if we can nurture precious human resource for achieving this. Kakodkar committees $[1,2]$ constituted by the Government of India for IITs (report submitted in April 2011) and NITs (June 2014) have made several recommendations for research oriented education system. The salient features of the observations and recommendations are:

IITs: Future lies in knowledge driven economy. Hence research should be an important component in education at IITs. IITs should aim at scaling the IIT system to 16,000 faculty and 160,000 total student strength (with 40,000, 40,000 and 80,000 at the $\mathrm{PhD}$, PG and UG levels, respectively) by around the year 2020. Each year, then, the IIT system will admit 10,000 PhDs and PGs each. IITs should tie up with premier Science and Technology institutes to attract the best students and faculty for their $\mathrm{PhD}$ programs. Attempt should be made to inspire third year undergraduate students to take up research as a career [1].

NITs: Some of the key areas that need to be recharged are high quality faculty, innovative research, excellent teaching, learning and evaluation methods, industry linkages, and institutional social responsibility. Moreover, the overriding aim of NITs must be to 
attract the brightest engineering talent in the country and shape them into excellent researchers or competent teachers. For that to happen, greater synergy must be developed with IITs and other reputed institutes [2].

The underlying theme is amalgamation of research and teaching in engineering institutes to generate technologically competent human resource as well as R\&D infrastructure which will spur and sustain a long term industrial and economic growth of India. Taking a cue from these guidelines for first and second rung institutes, the third rung engineering institutes should also start orienting their students towards R\&D and technology development.

\section{Problem}

The students of Engineering Undergraduate course (Bachelor of Engineering (BE)) under the Savitribai Phule Pune University (SPPU) have to carry out a project in the final year of their four year course. The project topics are obtained by the students from the industry or from the departments of the college. Due to several difficulties like lack of initiative, coordination and inadequate guidance, many of these projects do not come to a deployable level.

\section{Novel Paradigm}

We have therefore developed a novel paradigm.

Vishwakarma Institute of Information Technology (VIIT), Pune is a leading Undergraduate Engineering college in Pune. VIIT has a vision of imbibing the students with a zeal for innovation and excellence in their field of interest. Tata Institute of Fundamental Research (TIFR), Mumbai is a world renowned Research Institute.

Research laboratories are always devising experiments for observing natural phenomenon with higher and higher precision and resolution for pushing the limits of knowledge. Cosmic Rays Laboratory (CRL) of TIFR situated at Ooty aims at studying cosmic ray showers created by high energy $(\sim 1020$ $\mathrm{eV}$ ) charged particles (cosmic rays) coming from the outer space and is eminently lead by Prof (Dr) Sunil Gupta and Prof (Dr) Shashi Dugad. Prof S. Ramakrishnan from DCMPMS works in the field of Magnetism and Superconductivity at Micro-Kelvin temperatures. Dr S S Prabhu and Dr A V Gopal are engaged in research on Opto-electronics and
Plasmonics which could lead to futuristic technologies. These laboratories require development of high end instrumentation and software for data collection and analysis. VIIT, with 190 dedicated faculty and 600 final year (BE) students, is suited to take up this challenge.

\subsection{Modus Operandi}

The modus operandi of the collaboration is as follows:

- Students of third year (TE) are interviewed meticulously and their inclination towards independent thinking, urge to excel as an engineer and moral integrity are judged.

- The selected students are sent to CRL, Ooty/ TIFR, Mumbai for summer internship for 2-3 weeks. Faculty members of VIIT also visit for a week.

- The students interact with the scientists and engineers to understand the experiment and suggest possible projects they would like to take up.

- After due approval, the final year (BE) projects are taken up by the students.

- The most important aspect of this paradigm is that the responsibility of the project lies with the faculty and not the students. The faculty a) understands the project, b) determines the skill sets required for the project, c) finds out the initial skill set of the students and hence the gap between the skill set of the student and that required by the project and d) devises a training strategy to fill this gap.

- The students work on the project at VIIT under the guidance of faculty of VIIT. A separate laboratory has been established with state-of-the-art instruments for carrying out the TIFR projects. The laboratory is open for students even after college hours.

Strong interaction with scientists and engineers of TIFR through email, teleconferencing, etc is an important exercise to optimize the pace and direction of the project.

- Students visit CRL, Ooty/ TIFR, Mumbai once in each semester.

At the end, the students submit their hardware/ software to TIFR which is tested rigorously in the 
running experiment.

Since the projects are oriented towards developing the basic building blocks, these blocks are used by TIFR to adapt the developed technologies in several different contexts in their experiment.

- Many times, one of the students, who has actually developed the technology, joins TIFR and implements it in the scientific experiment.

- Next year, the selected students from TE start working with the previous year students which ensure continuity in work.

\subsection{Growth of Collaboration}

Collaboration between VIIT and TIFR started with one project and two students in the year 2009-10 from

\begin{tabular}{|c|c|c|c|c|l|}
\hline Year & $\begin{array}{c}\text { No. of } \\
\text { projects }\end{array}$ & $\begin{array}{c}\text { No. of } \\
\text { students }\end{array}$ & $\begin{array}{c}\text { No. of faculty } \\
\text { (VIIT) }\end{array}$ & $\begin{array}{c}\text { No. of scientists/ } \\
\text { engineers (TIFR) }\end{array}$ & $\begin{array}{c}\text { Departments } \\
\text { (VIIT) }\end{array}$ \\
\hline $2009-2010$ & 1 & 2 & 1 & 1 & E\&TC \\
\hline $2010-2011$ & 8 & 20 & 8 & 8 & E\&TC \\
\hline $2011-2012$ & 8 & 28 & 9 & 8 & E\& TC, Comp \\
\hline $2012-2013$ & 12 & 38 & 9 & 9 & E\& TC, Comp, IT \\
\hline $2013-2014$ & 15 & $\begin{array}{c}49 \\
(48+1 \mathrm{ME})\end{array}$ & 11 & 9 & E\& TC, Comp, IT \\
\hline $2014-2015$ & 15 & 45 & 10 & 10 & E\& TC, Comp, IT \\
\hline $\begin{array}{c}2015-2016 \\
\text { (on-going) }\end{array}$ & 19 & 64 & 12 & 10 & E\&TC, Comp, IT \\
\hline Total & 78 & 246 & & & \\
\hline
\end{tabular}

the Department of Electronics and Telecommunication (E\&TC). Departments of Computer Engineering (Comp) and Information Technology (IT) joined this collaboration in 2011-12 and 2012-13, respectively. The collaboration has

\begin{tabular}{|c|c|c|c|c|c|}
\hline Year & $\begin{array}{c}\text { No. of } \\
\text { projects }\end{array}$ & $\begin{array}{c}\text { No. of } \\
\text { students }\end{array}$ & $\begin{array}{c}\text { No. of faculty } \\
\text { (VIIT) }\end{array}$ & $\begin{array}{c}\text { No. of scientists } \\
\text { (IIA) }\end{array}$ & $\begin{array}{c}\text { Departments } \\
\text { (VIIT) }\end{array}$ \\
\hline $2014-15$ & $2(1 \mathrm{BE}, 1 \mathrm{ME})$ & 4 & 2 & 1 & E\&TC \\
\hline
\end{tabular}

blossomed over the years as indicated by the table below:

\begin{tabular}{|c|c|c|c|c|l|}
\hline Institute & $\begin{array}{l}\text { No. of } \\
\text { projects }\end{array}$ & $\begin{array}{l}\text { No. of } \\
\text { students }\end{array}$ & $\begin{array}{l}\text { No. of faculty } \\
\text { (VIIT) }\end{array}$ & $\begin{array}{l}\text { No. of scientists/ } \\
\text { engineers }\end{array}$ & $\begin{array}{l}\text { Departments } \\
\text { (VIT) }\end{array}$ \\
\hline IIA, Bengaluru & 2 & 4 & 1 & 1 & E\&TC \\
\hline IISER, Pune & 1 & 3 & 1 & 1 & E\&TC \\
\hline SPPU, Pune & 3 & 7 & 2 & 1 & E\&TC \\
\hline IUCAA, Pune & 1 & 4 & 1 & 1 & Comp \\
\hline Total & 6 & 18 & & & \\
\hline
\end{tabular}

\subsection{Beyond TIFR}

The success of VIIT-TIFR projects lead us to collaborating with other institutes like Indian Institute of Astro-Physics (IIA), Bengaluru in the year 2014-15

In the Academic Year 2015-16, collaboration was extended to several Research Institutes other than TIFR:

\section{Benefits}

\subsection{From VIIT perspective}

Our experience has been very exhilarating. The students learn the following:

- Defining a technical problem precisely

- Plan a course of action

- Execute the planned activities

- Review the results and re-plan

- Deploy and test the product in live experiment

- Give seminars/presentations thus developing oral communication skills

- Write reports thus developing writing skills

- Interact with teachers, scientists and peers thus developing skills to work in a team

The students thus develop overall technical as well as soft skills. Further, the technical know-how developed in a project is used as the base for the next year's BE project and hence the knowledge base in established and enhanced in the college which is directly used in TIFR laboratories. The foundation for long term collaboration has thus been laid.

The immediate benefits of this collaboration are:

- Research papers have been presented in International Conferences.

- Two students have received "National Photonics Fellowship". Out of these, one has completed MS and one is pursuing MS. 


\begin{tabular}{|c|c|c|c|c|c|}
\hline $\begin{array}{l}\text { Sr. } \\
\text { No }\end{array}$ & $\begin{array}{l}\text { Name of student } \\
\text { (BE Batch) }\end{array}$ & Project at TIFR & Post & $\begin{array}{l}\text { Lab at } \\
\text { TIFR }\end{array}$ & Present \\
\hline 1 & $\begin{array}{l}\text { Sanket Kamathe } \\
(2010)\end{array}$ & $\begin{array}{l}\text { Silicon Photo } \\
\text { Multiplier } \\
\text { (SiPM) }\end{array}$ & $\begin{array}{l}\text { Jr. Research } \\
\text { Fellow }\end{array}$ & \multirow[t]{6}{*}{\begin{tabular}{|l} 
Solid State \\
Electronics, \\
Mumbai
\end{tabular}} & MS-TU Darmstadt \\
\hline 2 & $\begin{array}{l}\text { Ameya Deshpande } \\
(2010)\end{array}$ & $\begin{array}{l}\text { Tera Hertz } \\
\text { Spectroscopy }\end{array}$ & $\begin{array}{l}\text { Jr. Research } \\
\text { Fellow }\end{array}$ & & $\begin{array}{l}\text { MS - North Carolina } \\
\text { State Univ, US }\end{array}$ \\
\hline 3 & $\begin{array}{ll}\text { Raj Patil (2011) } & \\
\text { Sev }\end{array}$ & $\begin{array}{l}\text { Plasmonics } \\
\text { NRIM eral }\end{array}$ & $\begin{array}{l}\text { National } \\
\text { Photonics } \\
\text { Fellowship }\end{array}$ & & $\begin{array}{l}\text { MS (pursuing)- Univ. of } \\
\text { Arizona, US }\end{array}$ \\
\hline 4 & Aniket Patil (2011) & $\begin{array}{l}\text { Plasmonic } \\
\text { Interconnects }\end{array}$ & $\begin{array}{l}\text { National } \\
\text { Photonics } \\
\text { Fellowship } \\
\end{array}$ & & $\begin{array}{l}\text { MS Univ. of Central } \\
\text { Florida, US }\end{array}$ \\
\hline 5 & Harshad Surdi (2012) & $\begin{array}{l}\text { Tera Hertz } \\
\text { Spectroscopy }\end{array}$ & $\begin{array}{l}\text { Jr. Research } \\
\text { Fellow }\end{array}$ & & Arizona State Univ. US \\
\hline 6 & $\begin{array}{l}\text { Prathmesh Deshmukh } \\
\text { (2014) }\end{array}$ & THz, Plasmonics & $\begin{array}{l}\text { Jr. Research } \\
\text { Fellow }\end{array}$ & & At TIFR \\
\hline 7 & $\begin{array}{l}\text { Raghunandan Shukla } \\
\text { (2011) }\end{array}$ & $\begin{array}{l}\text { SiPM, VLSI, } \\
\text { Embedded }\end{array}$ & $\begin{array}{l}\text { Scientific } \\
\text { Officer (C) }\end{array}$ & \multirow{3}{*}{$\begin{array}{l}\text { High } \\
\text { Energy } \\
\text { Physics, } \\
\text { Mumbai }\end{array}$} & At TIFR \\
\hline 8 & $\begin{array}{l}\text { Sarrah Lokahandwala } \\
\text { (2013) }\end{array}$ & $\begin{array}{l}\text { FPGA based } \\
\text { systems, SiPM }\end{array}$ & $\begin{array}{l}\text { Jr. Research } \\
\text { Fellow }\end{array}$ & & $\begin{array}{l}\text { University of Edinburgh, } \\
\text { UK }\end{array}$ \\
\hline 9 & Akhil Kurup (2014) & $\begin{array}{l}\text { FPGA based } \\
\text { systems, SiPM }\end{array}$ & $\begin{array}{l}\text { Jr. Research } \\
\text { Fellow }\end{array}$ & & At TIFR \\
\hline 10 & Suraj Kolhe (2012) & VLSI, Embedded & $\begin{array}{l}\text { Jr. Research } \\
\text { Fellow }\end{array}$ & \multirow{5}{*}{$\begin{array}{l}\text { Cosmic } \\
\text { Rays } \\
\text { Laboratory, } \\
\text { Ooty }\end{array}$} & M Tech, CoEP, Pune \\
\hline 11 & Serin V. John (2013) & $\begin{array}{l}\text { High voltage } \\
\text { DAS, Embedded }\end{array}$ & $\begin{array}{l}\text { Jr. Research } \\
\text { Fellow }\end{array}$ & & $\begin{array}{l}\text { MS (admitted) - TU } \\
\text { Chemnitz, Germany }\end{array}$ \\
\hline 12 & $\begin{array}{l}\text { Akshay Manjare } \\
(2014)\end{array}$ & $\begin{array}{l}\text { Embedded, } \\
\text { Instrumentation }\end{array}$ & $\begin{array}{l}\text { Jr. Research } \\
\text { Fellow }\end{array}$ & & At TIFR \\
\hline 13 & $\begin{array}{l}\text { Pankaj Rakshe BE } \\
\text { (2011), ME (2014) }\end{array}$ & $\begin{array}{l}\text { Embedded, } \\
\text { Instrumentation }\end{array}$ & $\begin{array}{l}\text { Scientific } \\
\text { Officer (D) }\end{array}$ & & At TIFR \\
\hline 14 & $\begin{array}{l}\text { Shubham Negi } \\
\text { (2015) }\end{array}$ & $\begin{array}{l}\text { Solar PV, } \\
\text { Instrumentation }\end{array}$ & $\begin{array}{l}\text { Jr. Research } \\
\text { Fellow }\end{array}$ & & At TIFR \\
\hline 15 & $\begin{array}{l}\text { Sameer Saraf (2013) } \\
\text { ents have gone }\end{array}$ & $\begin{array}{l}\text { Embedded } \\
\text { a broad tud }\end{array}$ & $\begin{array}{l}\text { Project } \\
\text { Engineer }\end{array}$ & $\begin{array}{l}\text { Atomic } \\
\text { Physics } \\
\text { Laboratory, } \\
\text { Mumbai }\end{array}$ & $\begin{array}{l}\text { MS (admitted) - } \\
\text { Michigan Tech. Univ, US }\end{array}$ \\
\hline
\end{tabular}

pursue MS and $\mathrm{PhD}$ in their fields of interest.

- Recruiters from companies give preference to students who have done TIFR projects during their oncampus placement activity.

Several students have joined TIFR and have worked/are working on several research projects. The details are:

Apart from this, the faculties get enriched as they are closely involved in development of technology thus making them more competent for teaching based on the solid foundation of R\&D.

\subsection{From TIFR perspective}

Several technologies developed in collaboration with VIIT have been deployed successfully in scientific experiments of TIFR. Few examples are enlisted below:

1) Field Programmable Gate Array (FPGA) and Microcontroller based 32 channel scalar developed by VIIT students has now been modified and is being used for 60-channel data acquisition (DAQ) card to measure count rate and pulse width of signal coming from Scintillator detector as well as proportional counter. It is also used to upgrade PCI based DAQ to USB protocol on a LINUX operating system. As the 
card is quite generic, it is used as a general purpose FPGAdevelopment board.

2) Monitoring of High voltage $(2500 \mathrm{~V}$ dc) with a resolution of less than a volt for multiple channels (18 in the prototype) which can transfer data through USB was developed by our students. Multiple boards with I2C capability is now being used in CRL for monitoring the close to 400 channels.

3) Solar Photovoltaic (PV) power system (3kW) has being developed by VIIT. Such a system with enhanced capability will be installed at CRL.

4) A 16-channel programmable power supply has been developed for Silicon Photo Multiplier (SiPM) with a capability of compensating for the temperature variation and keeping the variation in the gain of the SiPM to less than $0.5 \%$ per degree Celcius. The cost per channel is Rs 500/- only. There is so such instrument available in the world that too at such a low cost!

5) After graduating from VIIT, some of the students have joined TIFR and are now working on development of instrumentation for CMS experiment at CERN. They have designed and developed a DAQ for control, measurement and monitoring of neutron radiation for CMS detector. It is mounted in DAQ crate at P5 in CERN and is running without any glitch for several months now.

6) VIIT students have also developed a web based comprehensive data management system for 400 scintillator counters which has $\sim 100$ components. It keeps track of purchase, Quality Control, failure/ repair/replacement history of each component in each scintillator and creates analysis reports and alerts which help in keeping the system up and running $24 \times 7$.

7) ERP system manufacturing proportional counters has been developed. The manufacturing involves manufacturing $6 \mathrm{mx} 0.1 \mathrm{mx} 0.1 \mathrm{~m}$ MS tubes, stretching 100 micron tungsten wire, vacuum sealing, Argon filling and testing. The ERP system will also be used to deploy and monitor the proportional counters in the experiment.
8) Web based software has been developed for analysis of data and will dynamically generate plots through remote access by collaborators from anywhere in the world.

9) There are several power electronics projects in the pipeline.

\section{Memorandum of Understanding with TIFR}

As a result of the dynamic collaboration between the two institutes, VIIT and TIFR have signed a Memorandum of Understanding (MOU) for working together in the field of Research and Education. Prof S K Gupta and ProfC S Garde are the coordinators from TIFR and VIIT, respectively.

\section{Conclusion}

A novel paradigm has been developed where close collaboration between faculty and engineers from a college and a research institute helps to train students in development of technologies which are ultimately deployed in the laboratory of the research institute. It is thus a win-win situation for all the stake holders, i.e. students and faculty of the college and laboratories of the research institute.

\section{References}

[1] Taking IITs to excellence and greater relevance: Report of Dr Anil Kakodkar Committee April 2011

[2] NITs as drivers for higher technical education - the way forward: Kakodkar Committee Report June 2014

\section{Acknowledgements}

I would like to acknowledge the dedicated efforts of all the faculty and engineers of TIFR, VIIT and students of VIIT who contributed to the success of this collaboration. 